\title{
Pendekatan Penginjilan Kontekstual Kepada Masyarakat Baliem Papua
}

\section{The Contextual Evangelism Approach to the Baliem Papua Society}

\author{
Marde Christian Stenly Mawikere ${ }^{\mathrm{l})^{*}}$ \\ 1)Alumni Program Doktor Teologi Sekolah Tinggi Theologia Jaffray Makassar \\ *)Penulis korespondensi: mardestenly@gmail.com
}

Received: 16 January 2018/Revised: 5 February 2018 /Accepted: 17 March 2018

\begin{abstract}
Abstrak
Studi ini memperlihatkan adanya nilai-nilai budaya dan konsep worldview masyarakat Baliem yang "relatif dekat", yaitu kepercayaan kepada Walhowak atau Nyopase Kain atau Elalin Walhasikhe, konsep cargo cults berupa pengharapan situasi ideal masa depan dalam mitos Nabelan-Kabelan atau Nawulal-Hawulal atau Nabudlal-Habudlal atau Nabutal-Habutal atau Nanggonok-Kanggonok serta pengharapan oknum ideal masa depan dalam mitos Naruekul, serta sikap loyalitas kepada Ap Kain sebagai "kepala suku" akhuni Palim meke, sehingga dapat "dipertemukan" dengan nilai-nilai Injil melalui penggantian fungsi. Dengan demikian maka sangatlah memungkinkan untuk menentukan konsep pendekatan penginjilan kontekstual kepada mereka.

Kata-kata Kunci: Budaya, Nilai, Pandangan Dunia, Pendekatan, Penginjilan, Kontekstualisasi.

This study demonstrates the existence of cultural values and the concept of the worldview of the "relatively close" Baliem society, which is the belief in Walhowak or Nyopase Kain or Elalin Walhasikhe, the concept of cargo cults in the hope of the ideal situation of the future in the myths of Nabelan-Kabelan, Nawulal-Hawulal, Nabudlal-Habudlal, Nabutal-Habutal or Nanggonok-Kanggonok, as well as the hope of the future ideal person in the myth of Naruekul, as well as the attitude of loyalty to Ap Kain as the "head of the tribe" akhuni Palim meke, so as to be "reunited" with the values of the gospel through functional replacement. Thus it is possible to determine an approach concept of contextual evangelism for them.
\end{abstract}

Keywords: Culture, Values, Worldview, Approach Concept, Contextual Evangelism

\section{Pendahuluan}

Artikel ini membahas mengenai Pendekatan Penginjilan Kontekstual kepada Masyarakat Baliem Papua. Penulis akan memaparkan bagaimana memanfaatkan nilai-nilai budaya dan konsep pandangan dunia (worldview) masyarakat Baliem dalam upaya pendekatan penginjilan kontekstual. Dengan demikian akan meningkatkan upaya pemberitaan 
Injil yang kontekstual dengan menyentuh dan memberdayakan nilai budaya dan konsep pandangan dunia masyarakat Baliem. Hal ini menjadi penting supaya Injil dan kekristenan tidak sekadar sejarah atau monumen, tetapi tetap faktual dan transformatif dengan budaya dan situasi-kondisi masyarakat Baliem, Papua.

\section{Substansi Sosio-Kultural Masyarakat Baliem Papua}

Masyarakat Baliem di Papua dikenal dengan nama "orang atau suku Dani atau Ndani". Sekalipun demikian masyarakat sendiri menyebut diri mereka dengan nama sebagai "orang Hubula" atau "orang Baliem". Istilah Huwula atau Hugula adalah istilah asli yang kemudian disebut dengan aksen Hubula. Di samping itu orang Baliem senang menyebut diri mereka dengan istilah Palim Meke. Sebutan "orang Hubula atau Baliem" dalam bahasa ibu disebut akhuni Palim meke atau nit akuni Pallimeke yang berarti "kami orang dari Baliem". ${ }^{2}$ Sekalipun masyarakat Baliem pada awalnya tidak setuju dengan sebutan nama "Dani" atau Ndani kepada mereka, namun secara umum sudah terlanjur memakainya dalam laporan dan karangan etnografi, sehingga nama Dani tersebut yang sekarang dipakai secara resmi. ${ }^{3}$ Sebutan "masyarakat Baliem" dalam artikel ini memiliki alasan antropologi-etnografis. Lembah Baliem adalah jantung tanah Papua, sehingga masyarakat dataran tinggi Papua sering berkata: "apabila seseorang tidak datang ke Lembah Baliem, itu berarti bahwa dia tidak datang ke Papua”. Lembah Baliem adalah rumah bagi orang-orang suku bangsa Hubula, Lani, Ngalum, Ngalik, Nduga dan Yali. ${ }^{4}$ Demikian juga para antropolog lokal menyebut nama "orang Baliem" atau "manusia Baliem" untuk penduduk yang tinggal di Lembah Baliem, Papua. ${ }^{5}$ Karena itu, berdasarkan alasan antropologi-etnografi dan bahasa Ibu Ninane yang

'Frans Lieshout. Sejarah Gereja Katolik di Lembah Balim-Papua (Abepura-Jayapura: Sekretariat Keuskupan Jayapura, 2009), 18.

${ }^{2}$ Johszua Robert Mansoben, Sistem Politik Tradisional di Irian Jaya, Indonesia (Amsterdam: Universitas Leiden, 1994), 112; Lihat juga Koentjaraningrat, Masyarakat Terasing di Indonesia (Jakarta: Gramedia Pustaka Utama, 1993), 270.

${ }_{3}^{3}$ Johszua Robert Mansoben, Sistem Politik Tradisional di Irian Jaya, Indonesia, 109; Lihat juga Koentjaraningrat, Masyarakat Terasing di Indonesia (Jakarta: Gramedia Pustaka Utama), $1993,270$.

${ }^{4}$ Marthen Yadlogon Medlama, Welcome to The Baliem Valley Regency Papua (Wamena: Agamua Science, 2009), 5-6.

${ }^{5}$ Agus A. Alua, Nilai-Nilai Masyarakat Hubula di Lembah Balim Papua (AbepuraJayapura: Biro Penelitian STFT Fajar Timur, 2006), 1; Lihat juga A. Ibrahim Peyon, Antropologi Kontemporer Suatu Kajian Kritis Mengenai Papua (Jayapura: Kelompok Studi Nirentohon, 2012), 122. 
telah disebutkan di atas maka dalam artikel ini penulis menggunakan sebutan "masyarakat Baliem" kepada mereka.

Nilai-nilai Budaya (Cultural Values) Masyarakat Baliem

Nilai-nilai budaya masyarakat Baliem dapat diamati pada konteks pemukiman mereka yang disebut silimo. Adapun Silimo adalah halaman atau pekarangan yang dibangun terbentang luas dalam bentuk persegi. Pada bagian-bagian silimo terdapat rumah tinggal bagi laki-laki yang disebut honai atau pilamo, rumah bagi perempuan yang disebut eweai atau ebeai, dapur (hunila atau disela), kandang babi (wamaila atau lawula atau dabula), pekarangan (hakiloma), dan kolam masak (hakse-silimo). Melalui silimo inilah terjadi interaksi dan proses kehidupan sehari-hari masyarakat tradisional Baliem dalam mempertahankan kehidupan maupun identitas mereka yang juga menunjukkan nilai-nilai kehidupan orang Baliem sesungguhnya. ${ }^{6}$

Pada umumnya sikap hidup orang Baliem tidak pernah boleh menutup pintu rumahnya (honai/pilamo/eweai) maupun pemukimannya (silimo) terhadap orang lain. Suatu silimo haruslah bersifat terbuka untuk menerima dan merangkul semua orang karena kehidupan dipahami sebagai suatu sikap yang terbuka, merangkul, melingkupi, utuh dan harmoni dengan semua orang (lopologo atau lapolik). Suatu silimo tidak boleh tertutup dan egois, melainkan terbuka untuk siapa saja termasuk terbuka terhadap seorang musuh (ap silimeke) yang sedang mencari perlindungan karena suasana perang (tek mekogo walo kinogo ilik). Orang Baliem memiliki budaya yang disebut ikuni-akuni hinakmouphogo yang berarti sayangilah semua orang yang datang. ${ }^{7}$ Bahkan orang Baliem menyapa orang lain dengan sebutan netaiken yang berarti "engkau berada dihatiku/engkau bagian hatiku" untuk menunjukkan persaudaraan dengan orang lain. Orang Baliem tidak hidup terasing secara individu melainkan hidup bersama dalam suatu komunitas dengan orang-orang lain. ${ }^{8}$ Dengan demikian "nilai keterbukaan" adalah suatu nilai penting dalam kehidupan orang Baliem.

Sikap hidup orang Baliem yang terbuka pada semua orang dapat dilihat dalam "nilai makan bersama" atau nan atau nuok yang nampak dalam kehidupan mereka sehari-hari. Bagi orang Baliem sangat pantang untuk berkata "ini makananku", melainkan "ini makanan kita" (yimeke timeke nekarek meke). Bagi seorang anak yang sedang makan daging babi (nuok wam) tanpa membagikan dengan seorang teman (nayak) maka akan

${ }^{6}$ Johszua Robert Mansoben, Sistem Politik Tradisional di Irian Jaya, Indonesia, 120;Agus A. Alua, Nilai-Nilai Masyarakat Hubula di Lembah Balim Papua, 44-46.

${ }^{7}$ Agus A. Alua, Nilai-Nilai Masyarakat Hubula di Lembah Balim Papua, 47.

${ }^{8}$ Astrid Susanto-Sunario, Kebudayaan Jayawijaya Dalam Pembangunan Bangsa, 46. 
ditegur oleh ibunya (nausah) dengan berkata ilimeke-timeke nukunembe inowasi-weak, inayaklah inombe weat ilihik-lihik nekarek yang berarti "segala sesuatu yang dinikmati sendiri membuat badan berbau busuk, sebaliknya nikmatilah makanan bersama dengan teman, walau kecil sekalipun". Lagi pula dalam budaya orang Baliem dalam suatu komunitas silimo, maka mereka selalu berkata all usigiluk asokneat lagarek, ilimeke-timeke nagalukhe akuniat unom motok ape nagalukhe hano, etaiken werek yang berarti "orang yang memiliki hati baik dalam suatu silimo adalah seorang yang membuang kotoran seorang diri, namun apabila makan ia harus membagi untuk dinikmati bersama dengan orang lain". ${ }^{9}$ Nilai makan bersama ini menunjukkan keterbukaan orang Baliem dalam kehidupan sehari-hari yang memandang bahwa kehadiran orang lain adalah anugerah dalam kehidupan pada suatu silimo sehingga melawan semua sikap egois dan tertutup.

Adapun kehidupan bersama pada suatu silimo juga menjadi tempat pembelajaran berupa berbagi pengalaman hidup baik manis maupun pahit dari orang-orang tua kepada orang-orang muda. Dalam kebersamaan, entah di rumah laki-laki (honai atau pilamo) maupun di rumah perempuan (eweai atau ebeai) terjadi proses mengajar dan belajar yang mana orang muda menimba banyak pengalaman dari orang-orang tua. Kisah-kisah pengalaman hidup diceritakan, diantaranya siapa para leluhur dan kepercayaan orang Baliem, bagaimana berperang, bagaimana mulai berkeluarga, bagaimana mendapatkan sesuatu untuk memenuhi kebutuhan makanan, bagaimana relasi dengan orang lain dan sebagainya. Secara khusus pada eweai maupun hunila, maka seorang ibu (nausah) akan mengajar pada anak-anak perempuan (homarugih) mereka mengenai agosalak nyane ikenem holek (ketaatan pada perkataan ibu), ai yasusak elok (bisa menanam ubi), wam tasusak elok (bisa memelihara babi), agosalak yimi yamak elok (bisa membantu ibu-ibu), hopuru tasusak nen isasusak elok (bisa menggali ubi dan bisa memasak), hele owa luwu lawasek (bagaimana menjadi seorang gadis yang ramah) dan lain sebagainya. Demikian juga pada honai atau pilamo, seorang ayah (nopaseh) akan mengajarkan anak laki-laki (eaututek) mereka untuk opaselak nyane ikenem asuk holek (ketaatan pada perkataan ayah), yawu leget elok (dapat membuka lahan baru untuk berkebun), hali wasusak elok (bisa mencari kayu bakar), apuni yimi yamak (bisa menolong orang lain), wenekak egarek elok (mampu berkomunikasi dengan baik), aweuk ewelek (lihai dalam bertindak), owa isosek/isago

\footnotetext{
${ }^{9}$ Agus A. Alua, Nilai-Nilai Masyarakat Hubula di Lembah Balim Papua, 50.
} 
(menjadi laki-laki yang ramah) dan lain sebagainya. ${ }^{10}$ Karena itu, proses pendekatan mengajar dan belajar yang efektif bagi masyarakat Baliem adalah pada suatu silimo ketimbang pada kelas-kelas formal ataupun gedung pertemuan tertentu.

Nilai budaya lainnya yang dipegang erat oleh orang Baliem adalah nilai musyawarah sebagai bagian dari kebersamaan mereka pada suatu silimo. Pusat musyawarah dilaksanakan di honai dengan falsafah dasarnya adalah wenekak umanen at egarek, honainen at egarek, bunilanen egarekdek, itikmanen egarekdek, yang berarti apabila bermusyawarah haruslah di dalam rumah, bukan di luar rumah. ${ }^{.1}$ Dengan demikian seorang manusia dengan segala pendapat dan gagasannya didengar, dihargai dan dihormati serta melalui musyawarah di honai, orang Baliem juga menyatakan bahwa mereka menghargai dan menghormati roh-roh para nenek moyang (ame).

Nilai kerja adalah bagian penting yang dipegang oleh masyarakat Baliem. Pada suatu silimo, maka orang tua (nopaseh/ayah dan nausah/ibu) akan mengajarkan anak-anak mereka cara berkebun (yabu maniklago), mencari kayu bakar (o werasin), membuat pagar (leget), membuat rumah (oma), memasak (isasini), memelihara babi (kulik lago wam) dan berburu (apuni sue hageg watarek mek) sehingga akan menjamin kebutuhan hidup mereka. Adapun bagi orang Baliem, kerja (yabu hagatarek) memiliki makna penting, yaitu: Pertama, sebagai pernyataan harga diri yang mana seseorang memiliki nilai apabila ia bekerja. Kedua, bekerja adalah sebuah konsekwensi hidup yang mana apabila seseorang ingin hidup maka syarat mutlaknya adalah ia harus bekerja. Ketiga, sebagai kesempatan bagi seseorang untuk mengenal bakat, minat, kemampuan, ketrampilan, kekuatan dan daya tahannya. Keempat, sebagai alat untuk memperkuat kesatuan pada suatu pemukiman (silimo) maupun perkampungan (oukul) tertentu. $^{12}$

Beberapa nilai budaya yang telah dipaparkan di atas menunjukkan bahwa orang Baliem memiliki hinekerogo atau ninom hutik atau "nilai relasi" yang baik dengan falsafah dasar mereka bahwa manusia tidak memiliki arti tanpa kehadiran orang lain..$^{13}$ Akan tetapi dalam pengamatan penulis, saat ini "nilai relasi" tersebut makin memudar. Akumulasi dari perubahan sosial terutama berkaitan dengan konteks sosial politik yang telah

\footnotetext{
${ }^{10}$ Adnan Yelipele, Tradisi Dalam Perkawinan Adat Muslim Suku Dani Papua di Tinjau dari Hukum Islam (Pamekasan: STAIN Pamekasan, 2012), 45.

${ }^{11}$ Agus A. Alua, Nilai-Nilai Masyarakat Hubula di Lembah Balim Papua, 51.

${ }^{12}$ Astrid Susanto-Sunario, Kebudayaan Jayawijaya Dalam Pembangunan Bangsa (Jakarta: Lembaga Ilmu Pengetahuan Indonesia (LIPI) dan Pustaka Sinar Harapan, 1994), 56.

${ }^{13}$ Agus A. Alua, Nilai-Nilai Masyarakat Hubula di Lembah Balim Papua, 53.
} 
diungkapkan di atas telah memengaruhi orang Baliem untuk mulai tidak menerima kehadiran orang lain, terutama masyarakat pendatang yang mereka sebut "orang Melayu". Karena itu, saat ini orang Baliem berdiri dua kaki berkaitan dengan "nilai relasi" tersebut yang mana pada satu pihak budaya asli mereka menuntut adanya keterbukaan dan penerimaan terhadap orang lain serta sikap terbuka dengan perubahan. Namun pada pihak lain, konteks sosial budaya dan sosial politik telah membentuk eksklusivitas Melanesia atau Papua bagi orang Baliem sehingga mereka makin tidak menerima keberadaan orang lain dalam komunitas mereka. ${ }^{14}$

Nilai budaya terakhir yang masih menonjol dalam kehidupan masyarakat Baliem adalah nilai kepemimpinan atau at hagasek werekma. Seperti yang telah diungkapkan bahwa bagi masyarakat Baliem tidak terdapat seorang pemimpin yang diangkat dengan kualifikasi atau syarat tertentu. Pada umumnya orang yang kuat, berpengalaman, berhikmat, berwibawa, berani, baik hati dan tertua dipandang sebagai pemimpin yang dihormati yang disebut ap Kain. Karena itu, dalam budaya orang Baliem kepemimpinan tidak dipandang secara formalitas melainkan dilihat dari karisma, kekuatan dan otoritas seorang yang layak disebut sebagai ap kain. ${ }^{15}$ Orang-orang seperti itulah yang dapat menjadi teladan, dihormati dan didengar oleh setiap orang Baliem.

Sekalipun orang Baliem tidak memiliki pemimpin formal, namun mereka tetap menghormati pemimpin ap kain yang memiliki kekuatan, kewibawaan, karisma, hikmat, pengalaman dan teladan. Orang Baliem sering menyatakan mengenai ap kain dengan kalimat kan ati ayawu hano mare agoromi hano wogosek waga yang berarti oleh karena kepemimpinan orang itu maka sekarang kita dapat berhasil. Kepada ap kain yang demikian, maka orang Baliem akan menunjukkan loyalitasnya. Wujud loyalitas masyarakat terhadap pemimpin memengaruhi tingkah laku masyarakat dalam menganut agama maupun keinginan untuk maju. ${ }^{16}$ Karena itu, keterbukaan masyarakat Baliem terhadap pengaruh luar juga bergantung terhadap keterbukaan ap kain. Apabila ap kain memiliki keterbukaan, maka masyarakat akan mengikuti pemimpin dan terbuka pada perubahan serta mudah menerima dan berasimilasi dengan pendatang dengan tidak terlalu dibatasi oleh faktor agama.

${ }^{14}$ Lihat contoh-contoh kasus yang diungkapkan dalam buku-buku Alex Rumaseb, Sejarah Gereja Kemah Injil Indonesia di Tanah Papua (Bandung: Kalam Hidup, 2014) dan Kisruh Gereja Kemah Injil Indonesia di Tanah Papua (Bandung: Kalam Hidup, 2014).

${ }^{15}$ Johszua Robert Mansoben, Sistem Politik Tradisional di Irian Jaya, Indonesia, 121-123; Agus A. Alua, Nilai-Nilai Masyarakat Hubula di Lembah Balim Papua, 54.

${ }^{16}$ Adnan Yelipele, Tradisi Dalam Perkawinan Adat Muslim Suku Dani Papua di Tinjau dari Hukum Islam, 23-25. 
Pandangan Dunia (Worldview) Masyarakat Baliem

Pandangan dunia (worldview) masyarakat Baliem dibentuk oleh kepercayaan animisme-dinamisme. ${ }^{17}$ Karena itu, dalam konsep budaya masyarakat Baliem, "Tuhan" dipahami secara abstrak sebagai "realitas yang mutlak" yang disebut Walhowak atau Nyopase Kain. Masyarakat Huwula atau Palim/Baliem memercayai Walhowak sebagai Elalin Walhasikhe artinya Pencipta atau tidak ada awal dan tidak ada akhir atau Elalin. Bagi masyarakat Baliem, Walhowak dipercayai sebagai penguasa dunia dan sebagai Juruselamat manusia atau ari apuni yamagati lago atau apuni yamaga suguke, yang mana roh dari Walhowak yang disebut agoreke memiliki kekuatan sakral yang terdapat dalam bentuk kaneke.

Sekalipun Tuhan adalah "realitas yang mutlak", namun masyarakat tradisional memercayai Walhowak bukan sebagai "oknum" atau "pribadi", namun sesuatu yang abstrak atau tersembunyi yang termanifestasi melalui simbol berupa benda sakral seperti kaneke, hareken, su kepu, tunggan, tugi serta tempat-tempat tertentu seperti gunung (tom ukul), hutan (okama), rumah adat, pohon (o) atau gua (o mula) yang menjadi tempat tinggal roh-roh (wa laga meke areagun). ${ }^{18}$

Kepercayaan masyarakat Baliem kepada konsep Tuhan yang adalah realitas, namun abstrak juga dimanifestasikan kepada kepercayaan dan ketakutan terhadap "alam gaib". Alam gaib dipercaya sebagai kekuatan yang tidak kelihatan namun merupakan realitas yang menguasai gununggunung dan hutan yang bisa berwujud manusia biasa; laki-laki (ap) dan perempuan (himi) yang disebut Kugi Erimbo/Kwewanakwe dan penguasa kali (huli) dan rumput (oka heleka) yang disebut limbu.

Adapun penghayatan akan Tuhan (Walhowak) bagi masyarakat Baliem mengarah kepada masa lampau. Karena itu, di samping kepercayaan tersebut diungkapkan melalui simbol namun juga termanifestasi melalui kepercayaan terhadap leluhur/roh-roh orang mati sebagaimana yang kerap ditemukan dalam sistem kepercayaan masyarakat kuno yang animisme-dinamisme serta berbagai upacara atau ritual. Di Lembah Baliem, sejak dahulu sampai sekarang pada saat agamaagama telah masuk namun masih terdapat tempat pemujaan orang mati atau arwah yang disebut wakunmo. Wakunmo adalah bangunan kecil untuk meletakkan simbol-simbol penampakan (bierofani) para arwah yang baru meninggal (nyegehe) maupun arwah yang dipercayai tinggal di dalam guagua tertentu (inyawureke). Kehadiran para arwah tersebut diketahui

\footnotetext{
${ }^{17}$ Agus A. Alua, Karakteristik Dasar Agama-agama Melanesia (Abepura-Jayapura: Biro Penelitian STFT Fajar Timur, 2006), 15.

${ }^{18}$ Astrid Susanto-Sunario, Kebudayaan Jayawijaya Dalam Pembangunan Bangsa, 20;Lihat juga Agus A. Alua, Karakteristik Dasar Agama-agama Melanesia, 12.
} 
melalui fenomena alam dan melalui simbol bierofani berupa benda sakral tertentu terutama batu (elep) yang disebut kaneke. ${ }^{19}$

Demikian pula dengan upacara-upacara atau ritus-ritus yang dilaksanakan oleh masyarakat Baliem pada umumnya dipergunakan sebagai ungkapan solidaritas atau relasi dengan Walhowak, sesama (eperak) dan alam semesta (walowak), seperti: nesok aii (untuk memperkuat keseimbangan dengan manusia, hewan, tumbuhan dan alam semesta), wako (melawan penyakit), agat wesa (untuk kesuburan tanah dan panen tanaman), oka isago (hubungan manusia dengan batas wilayah/tanah), syilo, pawi (larangan tertentu), dan he yokel (penghormatan pada perempuan berkaitan dengan kesucian perkawinan). ${ }^{20}$ Karena itu, sekalipun masyarakat Baliem memahami "konsep Tuhan" sebagai Walhowak yang abstrak dan bukan ber-pribadi, namun "Tuhan" adalah sesuatu realitas atau nyata, sehingga masyarakat Baliem kerap berseru atau berdoa (wesa hagarik lagi) kepada Walhowak seperti: Li meke ti keme ero ete make (Sumber dari segala sumber), Pogot-Agat eki Legerek Make (raja atas langit dan bumi/yang mendasari langit-langit).

Bagi masyarakat Baliem dan seluruh Papua yang menjadi titik pusat dari kehidupan kosmos ini adalah keberadaan manusia itu sendiri. Sekalipun manusia menjadi fokus akan worldview masyarakat Baliem dan Papua mengenai alam semesta (universe), namun manusia tidak sendiri tetapi hidup dalam kebergantungan satu sama lain dengan matahari (morikin), tanaman terutama ubi (hepiri), binatang terutama babi (wam), batu-batu (elep), kali-kali (sike lisuok) dan roh-roh para leluhur (ame atau wa'laga meke areagun atau alawene oan kigidegma) serta Tuhan (Walhowak) yang abstrak namun terwujud dalam simbol-simbol seperti kaneke.

Generalisasi terhadap penghargaan masyarakat Papua/Melanesia terhadap "hidup" di atas terimplikasi dalam konsep mereka terhadap "hidup kekal" itu sendiri, seperti yang dihayati juga oleh masyarakat Baliem, Papua. Seperti halnya yang dihayati oleh segenap masyarakat Papua/Melanesia, maka bagi masyarakat Baliem konsep atau pemahaman mengenai "hidup kekal" terkait dengan pengharapan mesianis atau pengharapan masa depan yang kerap di sebut "kargoisme" (cargo cult) yang nampak dalam dua mitologi yaitu mitos Nabelan-Kabelan dan mitos Naruekul.

Mitos Nabelan-Kabelan atau Nawulal-Hawulal atau Nabudlal-Habudlal atau Nabutal-Habutal atau Nanggonok-Kanggonok yang berarti "pergantian kulitku dan kulitmu" atau "kulit lama diganti dengan kulit baru" merupakan legenda masyarakat Baliem yang memercayai bahwa "hidup

${ }^{19}$ Agus A. Alua, Karakteristik Dasar Agama-agama Melanesia, 12.

${ }^{20}$ Astrid Susanto-Sunario, Kebudayaan Jayawijaya Dalam Pembangunan Bangsa, 53-54. 
kekal" pernah ada dalam sejarah hidup manusia. Hidup baik pada permulaan kehidupan digambarkan sebagai hidup dalam suasana damai (hano), rukun bersama (hanorogo logosak owa), subur, sehat (owahano), berkelimpahan (nyamake motok apik) serta sejahtera (hanomotok). Manusia pada awalnya memiliki hubungan yang baik dengan sesamanya manusia serta harmoni dengan alam semesta. Kehidupan yang harmoni atau keadaan ideal merupakan asal dan tujuan yang telah membentuk worldview orang Baliem.

Menurut pandangan dunia (worldview) orang Baliem yang terkait dengan konsep kepercayaan dinamisme mereka, langit dan bumi pada mulanya terletak berdampingan seperti dua buah tangan. Di dalam sebuah lubang di dalam bumi hiduplah manusia dan hewan bersama-sama. Manusia pertama, Nakmaturi membuat guntur (o ku ku) dan memisahkan langit (pogot) dari bumi (elama yoma). Matahari (morikin) yang memiliki kekuatan yang disebut mo mengantar para penghuni lubang itu melalui pegunungan sampai dekat tempat yang bernama Apulakma (atau Seinma), tempat mereka itu muncul. Semuanya menikmati perdamaian (weny liolarekma). Seperti yang telah diungkapkan di atas, pada saat manusia mulai saling berkelahi (o inekin wilik eninoatarek) dan berperang (wim abiyokoi), maka di situlah Mo mulai menarik diri, pergi berdiri di langit (pogot) dan tidak mau memedulikan manusia lagi.

Dalam keadaan ideal bagi orang Baliem menunjukkan bahwa manusia (apuni) pada mulanya hidup bersama binatang-binatang (waloc). Tetapi binatang-binatang kemudian bertanya kepada manusia pertama Nakmaturi, siapa gerangan mereka? Dia lalu membagi-bagi mereka menurut jenis, terpisah dari manusia. Adalah suatu kenyataan yang terjadi pada manusia yang mana manusia saling bertengkar, berperang dan bermusuhan satu dengan yang lain. Maka berkatalah binatang-binatang itu kepada manusia: "kami juga tidak menyukai manusia, kami ingin berdiri sendiri". ${ }^{21}$

Keadaan ideal tersebut menjadi rusak dan hilang pada saat manusia saling bertengkar, berkelahi, berperang dan bermusuhan satu dengan yang lain. "Dosa relasional" ini mengakibatkan hilangnya kelimpahan hidup dan damai antara sesama manusia serta musnahnya kebersamaan hidup yang pernah terjalin. Kini manusia harus berhadapan dengan masalah retaknya hubungan dengan sesama manusia, lingkungan dan alam semesta (keretakan yang bersifat horizontal) dan tidak memiliki kaitan langsung dengan Walhowak sebagai Nyopase Kain (hubungan vertikal). Di tengah-tengah suasana relasi yang tidak harmonis antara manusia dan sesamanya serta lingkungan alam sekitarnya, maka

\footnotetext{
21Jan Boelaars, Manusia Irian-Dahulu, Sekarang, Masa Depan, 120.
} 
timbullah kerinduan dalam diri manusia untuk kembali menciptakan suasana atau kondisi permulaan sejarah manusia yang ideal dan penuh damai sejahtera, supaya suasana tersebut datang kembali pada masa kini. Pengharapan masyarakat Baliem tersebut harus ditempuh dengan perjuangan untuk membangun kembali suasana yabu taman hagarek atau "Taman Eden" yang harmoni di atas puing-puing kehancuran dan keretakan yang merupakan kebutuhan, cita-cita dan tujuan hidup mereka. Karena itu, pada kemudian hari muncullah idiom tradisional Yogotak hubuluk motok hanorogo (hari esok akan menjadi lebih baik dari hari ini) yang kemudian menjadi semboyan masyarakat Baliem kontemporer dalam realitas pembangunan lintas sektoral.

Di tengah pengharapan kembalinya "yabu taman hagarek atau Taman Eden" dan segala suasananya yang indah dan damai, maka muncullah legenda Nabelan-Kabelan atau Nawulal-Hawulal atau Nabudlal-Habudlal atau Nabutal-Habutal atau Nanggonok-Kanggonok. Menurut legenda tersebut, nenek moyang masyarakat Baliem menyesal atas burung (sue) yang bernama Ibibilo atau Pirigobit yang kecepatannya selalu mendahului ular (pelal atau walo) yang bernama Bonon. Padahal sue Ibibilo atau Pirigobit tidak pernah berganti kulit dan langsung mati. Tetapi burung tersebut memiliki sayap dan bisa terbang mendahului kecepatan pelal Bonon yang memang sering berganti kulit lama dengan kulit baru namun lambat kecepatannya dibandingkan sue Ibibilo atau Pirigobit. Ular hanya bisa merayap di tanah dan mengikuti dari belakang, namun kalah dibandingkan kecepatan sue Ibibilo atau Pirigobit yang sebenarnya tidak panjang umur. Leluhur masyarakat Baliem menyesal akan keadaan ini, sebab apabila situasinya terbalik, yaitu pelal Bonon mendahului kecepatan sue Ibibilo atau Pirigobit, maka manusia selalu berganti kulit dan akan hidup selama-lamanya. Artinya manusia akan memperoleh situasi ideal yang indah dan damai serta harmoni dengan sesamanya selama-lamanya sebagai sintesis dari legenda burung Ibibilo atau Pirigobit dan ular Bonon tersebut.

Karena itulah masyarakat Palim/Huwula memahami mitos NabelanKabelan atau Nawulal-Hawulal artinya hidup kekal. Tidak ada awal kelahiran dan tidak ada akhir kematian. Hanya berganti kulit. Ini adalah kata-kata ular atau palu atau pelal dan sejenisnya yang disebut Niniluk Motok. Nabelan-Kabelan atau Nawulal-Hawulal tandanya adalah ular selalu berganti kulit yang merupakan simbol dari sukacita.

Pada akhirnya muncullah nubuatan mengenai akan hadirnya Nabelan-Kabelan atau Nabutal-Habutal atau Nanggonok-Kanggonok pada suatu masa di tengah kehidupan masyarakat Baliem. Di mana akan terjadi "pergantian kulit lama dengan kulit baru". Dengan kata lain sue pirigobit yang melambangkan kematian (wahlagecarekma) akan diganti dengan pelal 
bonon yang melambangkan pergantian kulit atau kebangkitan (eluk aga). Masyarakat Baliem tidak mengetahui caranya memperoleh "pergantian kulit" (Nabelan-Kabelan) tersebut, namun dari nenek moyang mereka sejak zaman dahulu memercayai, mengharapkan dan mengajarkan/ menubuatkan akan kedatangan Nabelan-Kabelan tersebut.

Adapun melalui mitos Nabelan-Kabelan atau Nabutal-Habutal atau Nanggonok-Kanggonok memberikan gambaran mengenai konsep hidup kekal masyarakat Baliem, Papua yang tidak bersifat filsafat-doktrinaldogmatis (pengajaran) tetapi lebih kepada eksistensial-praktis (keberadaan dan pengalaman).

Dengan demikian dapat disimpulkan bahwa sejak dahulu kala, leluhur masyarakat Baliem merindukan situasi dan kondisi yang ideal, indah, damai, sejahtera, harmonis di dalam dirinya sendiri maupun dalam relasi dengan sesama manusia dan alam sekitarnya pada masa kini. Namun kondisi tersebut belum terwujud pada masa kini, namun menjadi pengharapan akan "masa depan" yang segera akan terwujud dengan kedatangan Nabelan-Kabelan atau Nabudlal-Habudlal atau Nawulal-Hawulal atau Nabutal-Habutal atau Nanggonok-Kanggonok yang bercorak kargoisme (cargo cult).

Selain mitos Nabelan-Kabelan yang menjadi kepercayaan kuat bagi masyarakat Baliem, maka terdapat kepercayaan lain melalui mitos Naruekul yang juga merupakan legenda yang memiliki muatan cargo cult seperti halnya legenda Nabelan-Kabelan tersebut. Alkisah pada zaman permulaan para leluhur masyarakat Baliem hidup dalam keadaan aman, damai dan bersatu antara sesama manusia dan lingkungan alam semesta. Namun muncullah seorang laki-laki (ap atau elege) bernama Naruekul yang penampilannya berbeda dari pada semua orang lain. Pada masa hidupnya, Naruekul sering melakukan perjalanan dari kampung ke kampung dan dari satu daerah ke daerah lainnya sehingga Naruekul menjadi terkenal. Akibatnya banyak masyarakat menjadi takut kepadanya, jangan sampai orang hidup di bawah pengaruh dan kuasanya.

Dalam kondisi yang terkenal dan menimbulkan ketakutan masyarakat terhadap Naruekul, maka muncullah persekongkolan rahasia dari beberapa orang untuk membunuh Naruekul. Hal ini menjadi nyata, sehingga nyawa Naruekul dibunuh dan ia meninggal. Jenazah Naruekul kemudian dipotong-potong dan dibagi-bagikan kepada masyarakat. Pembagian potongan jenazah Naruekul tersebut, karena masyarakat dari segenap lapisan dan penjuru menginginkannya dengan saling rebut dan rampas warek atau potongan jenazah dari Naruekul.

Adapun masyarakat Baliem mengkultuskan potongan jenazah Naruekul dan sampai sekarang mempersonifikasikan dalam benda dan 
tumbuhan tertentu, yaitu: Pertama, batu kaneke yakni batu suci, harta warisan leluhur yang diyakini diambil dari tulang-tulang (oak) Naruekul. Kedua, benda Ye serupa dengan kaneke dipakai sebagai alat pembayaran mas kawin, utang piutang yang juga diambil dari tulang Naruekul. Ketiga, tumbuhan hepiri nesok ukut artinya petatas tumitku, hepiri okenpalek artinya petatas gumpalan darahnya, hepiri wimoak artinya sepotong ruas bambu yang dipakai untuk membunuh dan memotong Naruekul bertumbuh menjadi petatas hepiri ab ella artinya petatas urat dahinya (pria). Keempat, tumbuhan El tellu, yaitu tebu berwarna merah tua, dari mep apusu atau darah dari Naruekul. ${ }^{22}$

Pembagian potongan jenazah Naruekul menjadi tidak adil di tengah masyarakat sebab ada yang dapat dan ada juga yang tidak mendapatkan apa-apa. Pada akhirnya masyarakat yang menghendaki pembagian potongan jenazah Naruekul membubarkan diri dan kembali ke kampung masing-masing (osili) serta menyembunyikan warek atau potongan jenazah dari Naruekul yang berhasil dimiliki menjadi milik pribadi.

Pada suatu hari di tengah sekelompok orang yang sedang berjalan melintasi tempat di mana Naruekul dibunuh, muncullah Naruekul menampakkan diri kepada mereka. Orang-orang yang melihat Naruekul menjadi takut, gentar dan bingung. Akan tetapi Naruekul memperkenalkan dirinya bahwa yang berdiri di hadapan mereka adalah sungguh dia yang pernah hidup, dibunuh, jenazahnya dipotong-potong dan disembunyikan orang sebagai milik pribadinya tersebut. Sesudah menampakkan dirinya maka Naruekul memberikan pesan (apuni nen kino egarek) sebagai janji (wene werek) bagi orang-orang yang menyaksikannya sebagai berikut: Pertama, janganlah apa yang telah diambil, yakni warek atau potongan jenazahnya disembunyikan sebagai milik pribadi, melainkan jadikanlah itu sebagai milik bersama kelompok/ komunitas/klen. Kedua, bagian tubuh Naruekul yang telah direbut haruslah dinamakan kaneke (benda sakral) yang berarti "engkau punya buah hati," "engkau punya buah tubuh". Ketiga, bagian tubuh Naruekul akan menjadi sumber kehidupanmu dan sumber kehidupan keturunanmu untuk sepanjang masa. Keempat, bagian tubuh Naruekul akan menjadi kaneke dan kaneke akan menjadi nyakla kagalerek meke atau sumber inspirasi. Kelima, setiap kelompok/komunitas/klen akan terpecah belah akibat perselisihan di antara kelompok/komunitas/klen tersebut dan akan membentuk kaneke. $^{23}$

${ }^{22}$ Agus A. Alua, Nilai-nilai Hidup Masyarakat Hubula di Lembah Balim Papua, 32-33.

${ }^{23}$ Jan Boelaars, Manusia Irian-Dahulu, Sekarang, Masa Depan, 121;Agus A. Alua, Nilainilai Hidup Masyarakat Hubula di Lembah Balim Papua, 32. 
Konon setelah Naruekul menyampaikan pesan atau janjinya, bertiuplah angin kencang (segeik) dan Naruekul terangkat ke langit (pogot). Masyarakat yang menyaksikan peristiwa tersebut menjadi takut dan melarikan diri. Mereka berkumpul dan bertanya-tanya mengenai apa yang mereka alami dalam peristiwa penampakkan Naruekul tersebut. Adapun berita mengenai penampakkan dan janji Naruekul tersiar ke seluruh daerah. Masyarakat menjadi takut, sebab ternyata Naruekul yang terbunuh dengan tragis bukan manusia biasa melainkan Walhowak yaitu Nyopase Kain pogot kenak helalike meke atau Tuhan yang menciptakan bumi dan segala isinya. Karena itu, masyarakat berseru: "Baiklah sekarang kita harus berpegang teguh semua yang ia (Naruekul) pesan/janji dan melaksanakannya serta menjadikannya sebagai pegangan hidup dan mewariskannya kepada anak cucu kita”. ${ }^{24}$

Dengan demikian maka bagi masyarakat Baliem, Naruekul dipercayai sebagai tokoh ajaib yang pernah hidup dan menjadikan segalanya. Naruekul yang juga disebut Nakmarugi atau Alabungi, Nalabungi, Limlangi dan Yeli oleh orang-orang Yali di Yalimo atau juga disebut Murumnah Nalaponge dan Yelu oleh orang-orang Yali dan Mek di Yahukimo adalah inti, asal, tokoh dan manusia ajaib dalam struktur internal budaya di Lembah Baliem dan sekitarnya. ${ }^{25}$

Seluruh masyarakat lokal Papua yang bermukim di Lembah Baliem dan sekitarnya memercayai bahwa sesungguhnya Naruekul adalah Walhowak atau Nyopase Kain yaitu Tuhan yang menciptakan manusia, tumbuhan, binatang, sungai, danau, gunung, lembah, cara hidup dan budaya manusia. Dalam gerak tersebut, Naruekul menjadi asal atau inti yang menciptakan segala sesuatu melalui pengorbanan dirinya. Naruekul telah dilukai, terbunuh, mati, dipenggal-penggal dan dimasak bagianbagian dari penggalan-penggalan tubuhnya tersebut dan melalui pengorbanannya itu terciptalah kehidupan. Naruekul harus hidup kembali dan mengulang hal yang sama sehingga kebutuhan akan kehidupan ini dapat terpenuhi. Melalui mitologi Naruekul diperlihatkan dosa manusia yang melukai tubuh dan hati dari Naruekul yang sebenarnya merupakan inti dari kehidupan manusia melalui kekerasan, namun Naruekul tidak melakukan pembalasan. Seperti yang telah diungkapkan di atas, dibalik segenap tindakan kekerasan manusia atas hidupnya, Naruekul malah berpesan bahwa jadikanlah segala bagian dari tubuhku yang dirampas sebagai milik kelompok, mendirikan rumah suci dan simpanlah bagian

${ }^{24}$ Agus A. Alua, Nilai-nilai Hidup Masyarakat Hubula di Lembah Balim Papua, 32.

${ }^{25}$ Zollner, Siegfried. Pohon Yeli dan Mitos Wam dalam Agama Orang Yali (Germany: Penerbit Wahine, 2011), 35; Lihat juga A. Ibrahim Peyon, Antropologi Kontemporer Suatu Kajian Kritis Mengenai Papua (Jayapura: Kelompok Studi Nirentohon, 2012), 124. 
tubuhku di sana, dan sembahlah kepadaku. ${ }^{26}$ Pesan dari Naruekul tersebut telah hidup di dalam inti kehidupan manusia Baliem yaitu kaneke yang dipercayai sebagai tempat berdiam Naruekul, inti kehidupan manusia Baliem.

Adapun dengan mitos Naruekul ini, maka penghayatan masyarakat Baliem akan konsep hidup kekal telah berkembang dari pengharapan situasi atau kondisi ideal seperti yang nampak dalam mitos NabelanKabelan kepada pengharapan kepada "oknum atau pribadi" dalam hal ini pribadi Naruekul. Sekalipun mengalami kehidupan yang ideal dan terkenal serta peristiwa yang tragis, namun Naruekul adalah pribadi yang berkuasa yang muncul kembali setelah mati dan jenazahnya dipotong-potong dan dibagi-bagikan serta disembunyikan menjadi milik pribadi. Naruekul seperti "oknum" atau "pribadi" yang berkuasa menampakkan dirinya kepada orang-orang tertentu serta memberikan pesan atau janji bagi kondisi atau situasi ideal masyarakat masa kini dan keturunannya. Karena itu, Naruekul kemudian dipercayai bukan sebagai manusia biasa lagi, namun adalah Walhowak yaitu Tuhan yang menciptakan bumi dan segala isinya (Nyopase Kain pogot kenak helalike meke).

Dengan demikian masyarakat Baliem memiliki pengharapan mesianis yang dikenal sebagai "kargoisme" baik situasi yang ideal dengan pergantian kulit lama dengan kulit baru atau situasi lama yang buruk/kematian dengan situasi baru yang damai dan hidup (yang nampak dalam mitos Nabelan-Kabelan) serta pengharapan akan pribadi/oknum yang ideal yang adalah seorang manusia sekaligus Tuhan (Walhowak) yang menderita sampai mati, namun memberikan janji dan pengharapan bagi manusia dan keturunannya. Baik mitos "oknum yang ideal" (Naruekul) maupun "keadaan yang ideal" (Nabelan-Kabelan) telah membentuk pandangan dunia (worldview) orang Baliem mengenai adanya masa depan yang memercayai bahwa Tuhan (Walhowak) adalah "model asal" mereka. ${ }^{27}$ Orang Baliem memiliki pengharapan kepada Walhowak sebagai sumber dan tujuan hidup mereka sekalipun samar-samar sebagai Nyopase Kain yang tidak dikenal pribadinya.

Bahkan melalui mitos Nabelan-Kabelan ini telah membentuk pandangan dunia orang Baliem tentang adanya hidup setelah mati yang dipegang dari generasi ke generasi.

Adapun karakteristik pengharapan kargoisme di Papua yang juga nampak pada masyarakat Baliem adalah sebagai berikut: Pertama, pengharapan akan adanya suatu perubahan sosial, ekonomi, status dan

\footnotetext{
${ }^{26}$ A. Ibrahim Peyon, Antropologi Kontemporer Suatu Kajian Kritis Mengenai Papua, 125.

27Jan Boelaars, Manusia Irian-Dahulu, Sekarang, Masa Depan, 122.
} 
tatanan alam. Kedua, pengharapan akan adanya suatu tatanan hidup baru, dunia baru sama seperti yang pernah dialami pada masa lampau. Ketiga, tuntutan untuk mengadakan ritus-ritus religi dalam mempercepat kedatangan kargo, dunia dan kehidupan baru. Keempat, pengharapan bahwa leluhur dan nenek moyang yang telah pergi akan kembali bersamasama dengan Mesias atau seorang nabi yang akan membawa serta kargo, makanan, pakaian, uang, kemajuan ekonomi dan teknologi, kebebasan dari segala bentuk tekanan, pengetahuan, kedamaian, keadilan sosial, status dan semua yang dianggap baik bagi suatu kehidupan yang berhasil. ${ }^{28}$

Dengan kata lain, bagi orang Baliem prinsip-prinsip kargoisme yang terdapat pada mitos Nabelan-Kabelan dan mitos Naruekul itu berhubungan dengan harapan dan impian masyarakat Baliem untuk memperoleh sesuatu baik berupa zaman bahagia seperti di Taman Eden, pengakuan, status, kekayaan, kedamaian serta peningkatan taraf hidup yang lebih baik.

Prinsip-prinsip kargoisme Nabelan-Kabelan (situasi ideal) dan Naruekul (oknum ideal) tersebut selalu diceritakan oleh orang tua kepada anak-anak mereka di dalam honai di silimo masing-masing di sekitar api unggun (hetuk) pada setiap malam (iwakoh) sebelum mereka tidur sebagai suatu pesan turun-temurun sehingga menjadi worldview yang dipegang oleh seseorang sejak kecil yang orang Baliem sebut nyakla ewetarek meke atau ideologi.

Substansi Sosio Kultural dan Korelasinya Dengan Pendekatan Penginjilan Kontekstual yang Relevan Kepada Masyarakat Baliem

Seperti yang telah dipaparkan di atas bahwa pandangan dunia (worldview) masyarakat Baliem yang dibentuk oleh nilai-nilai budaya tradisional yang masih terpelihara sekalipun perubahan demi perubahan terus terjadi, di antaranya: kepercayaan terhadap Walhowak sebagai Nyopase Kain atau Tuhan yang abstrak, keberadaan roh-roh nenek moyang yang nyata (areagun nyopa nyapu), simbol-simbol kepercayaan kepada Walhowak yang berwujud kaneke, ritus-ritus yang mementingkan kebersamaan melalui pesta babi (eweako), pengharapan mesianis/ kargoisme yang nampak pada mitologi Nabelan-Kabelan dan Naruekul, penghargaan terhadap kepemimpinan tradisional yaitu Ap Kain serta besarnya perubahan budaya yang dipengaruhi oleh pemberitaan Injil (Allah ene palek), integrasi dengan Indonesia serta perubahan karena perkembangan zaman sampai sekarang ini.

${ }^{28}$ Benny Giay, Kargoisme di Irian Jaya (Sentani: Region Press, 1986), 26-27. 
Dengan keberadaan seperti itu, maka sebenarnya masyarakat Baliem tergolong pada masyarakat tradisional yang tetap mempraktikkan kepercayaan animisme-dinamisme sekalipun sudah menganut agamaagama formal. ${ }^{29}$ Penganut anismisme-dinamisme memahami bahwa kekuatan-kekuatan adikodrati (Tuhan, Malaikat, Setan, Roh-roh jahat) merupakan suatu realitas dan memengaruhi kehidupan mereka. ${ }^{30}$ Karena itu, ketergantungan dan keterpesonaan terhadap kuasa adikodrati tersebut demi keselamatan yang utuh yang mencakup jasmani dan rohani merupakan hal yang penting bagi masyarakat tradisional seperti orang Baliem yang memercayai Walhowak dan kaneke maupun pengharapan masa depan yang ideal dalam mitologi Nabelan-Kabelan dan Naruekul.

Sesuai dengan kepercayaan orang Baliem terhadap roh-roh nenek moyang (areagun nyopa nyapu) dan kekuataannya yang disebut atou yang tersimpan dalam batu keramat kaneke, maka hal ini menunjukkan bahwa orang Baliem memandang adanya kesinambungan antara dunia empiris di bumi ini dengan dunia rohani yaitu transenden yang melampaui konteks kehidupan saat ini. Dunia roh (areagun) memiliki pengaruh terhadap dunia empiris, namun tidak sebaliknya. Meskipun seseorang telah meninggalkan dunia empiris di bumi ini, arwahnya (nyegehe atau inyawureke) masih bisa memengaruhi dunia empiris ini dari dunia roh (areagun).

Pembelajaran terhadap segala kepercayaan telah banyak diketahui, baik kepercayaan primitif seperti animisme-dinamisme maupun agamaagama formal perlu menjadi pertimbangan penting dalam pemberitaan Injil secara lintas budaya dan kontekstual. ${ }^{31}$ Dengan demikian, maka aspek-aspek kepercayaan orang Baliem mengenai Walhowak, areagun nyopa nyapu, kaneke maupun pengharapan masa depan yang ideal dalam mitologi Nabelan-Kabelan dan Naruekul harus menjadi pertimbangan penting untuk merumuskan konsep pendekatan penginjilan kontekstual kepada mereka.

Orang Baliem tidak memiliki sistem kepemimpinan formal, namun hal itu terungkap dalam sistem kepemimpinan tradisional berdasarkan pada pertimbangan akan karisma, kekuatan, keberanian, hikmat dan keteladanan seseorang yang layak menjadi pemimpin yang disebut ap kain. Sikap ketaatan atau loyalitas orang Baliem terhadap ap kain telah menjadi gaya hidup mereka hingga saat ini sekalipun sistem pemerintahan formal telah diberlakukan sejak Papua berintegrasi dengan Indonesia. Dengan sistem kepemimpinan ap kain tersebut, maka kuasa dan wibawa para

${ }^{29}$ Agus Alua, Permulaan Pekabaran Injil di Lembah Balim, 105-107.

${ }^{30}$ Aida Besancon Spencer, The Global God-Listening To God And Learning From Culture (Grand Rapids: Baker Books, 1998), 146-160.

${ }^{31}$ Mathias Zahniser, Symbol And Ceremony-Making Disciples Across Cultures (California: MARC-World Vision International, 1997), 58-66. 
pemimpin dalam masyarakat Baliem tidak berdasarkan faktor intelektualitas maupun penguasaan ilmu tertentu, melainkan berdasarkan pada kekuatan adikodrati yang dimiliki oleh seorang pemimpin. Karena itu, faktor kepemimpinan yang nampak dalam karakteristik kelompok suku bangsa tertentu, harus menjadi pertimbangan dalam melaksanakan pendekatan penginjilan yang kontekstual kepada suatu kelompok masyarakat tertentu. ${ }^{32}$

Selama ini safari pekabaran Injil yang dilakukan oleh para misionari dan gereja kurang menyentuh aspek at hagasek werekma yaitu kepemimpinan para ap kain tersebut, namun lebih menekankan pada pembakaran benda-benda sakral seperti kaneke yang banyak dipegang oleh para ap kain..$^{33}$ Karena itu, aspek at hagasek werekma dari para ap kain ini harus menjadi pertimbangan penting untuk merumuskan konsep pendekatan penginjilan kontekstual kepada masyarakat Baliem.

Pada satu pihak masyarakat Baliem sangat terbuka dengan pengaruh luar sejauh tidak menghilangkan nilai-nilai budaya masyarakat setempat. Sikap masyarakat Baliem terhadap perubahan sangat tergantung apabila membuat masyarakat berkembang, baik dalam aspek ilmu pengetahuan dan teknologi, serta pertumbuhan ekonomi, pendidikan dan kesehatan sesuai dengan pandangan dunia mereka mengenai keselamatan yang bersifat material yang bertumpu pada pengharapan kargoisme mengenai situasi yang ideal (Nabelan-Kabelan) dan pribadi yang ideal (Naruekul). Dengan kata lain, masyarakat menginginkan perubahan yang menyentuh kebutuhan hidup atau mensejahterakan masyarakat secara utuh/holistik serta tidak bertentangan dengan nilai budaya orang Baliem. Karena itu, upaya untuk merumuskan pendekatan penginjilan yang kontekstual bagi masyarakat Baliem dapat memperoleh pijakan sejauh tidak merusak atau menghilangkan nilai-nilai budaya masyarakat (welagegorek owa) sebab perubahan budaya merupakan aspek penting dalam kesaksian Kristen. ${ }^{34}$

Konsep keselamatan orang Baliem yang bersifat sekarang dan konkret serta menyentuh segenap aspek kehidupan yang utuh, baik rohani maupun jasmani yang disebut nyewe hanorogo yagelogosak sebenarnya

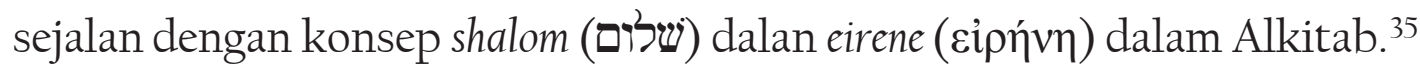
295.

${ }^{32}$ Paul G. Hiebert, Cultural Anthropology (Michigan: Baker Book House, 1998), 275-

${ }^{33}$ Agus Alua, Permulaan Pekabaran Injil di Lembah Balim (Abepura-Jayapura: Biro Penelitian STFT Fajar Timur, 2006), 98-102; James Sunda, Pertumbuhan Gereja Di Pegunungan Tengah Papua (Jayapura: Ondewerek, 2012), 32-35.

${ }^{34}$ Pembahasan yang panjang mengenai hal ini dijabarkan oleh Charles Kraft, Anthropology For Christian Witness (Maryknoll-New York: Orbis, 1996), 358-446.

${ }^{35}$ Agus A. Alua, Karakteristik Dasar Agama-agama Melanesia, 49. 
Karena itu, konsep pemberitaan Injil yang kontekstual kepada orang Baliem tidak cukup hanya menekankan dan menyentuh hal rohani (inegehe), melainkan merupakan upaya transformasi kehidupan yang utuh yaitu jasmani dan rohani/holistik (ewe mel areagun mel, owa op lek hano) sebagai hakikat dari pada misi Kerajaan Allah. ${ }^{36}$

\section{Konsep Pendekatan Penginjilan Kontekstual Kepada Masyarakat Baliem Papua}

Konsep Pendekatan Penginjilan Kontekstual Melalui Kepercayaan Akan Tuhan

Untuk memperkenalkan mengenai Tuhan kepada masyarakat Baliem, maka dapat menggunakan kepercayaan kuno masyarakat Baliem kepada Walhowak sebagai Nyopase Kain yang adalah Tuhan atau realitas yang mutlak/sumber asal, maka seorang pemberita Injil atau Allah ene palek wolok negarek meke tetap dapat menggunakan istilah (form) Walhowak atau Nakmarugi atau Naruekul dalam menyampaikan Injil atau Allah ene palek. Pemakaian istilah Walhowak atau Nakmarugi atau Naruekul tentunya digunakan dengan makna (meaning) yang berbeda dengan pemahaman masyarakat Baliem. Konsep orang Baliem mengenai Walhowak atau Walhasikhe Elalin sebagai Nyopase Kain (Tuhan), Li meke ti keme ero ete make (Sumber dari segala sumber), Pogot-Agat eki Legerek Make (raja atas langit dan bumi/yang mendasari langit-langit) harus memperoleh adaptasi dalam pemberitaan Injil kontekstual kepada mereka. Hal ini dimungkinkan dengan adanya fungsi peran pengganti (functional substitute), yaitu upaya mempertahankan istilah atau bentuk (form) seperti yang dikenal dalam konteks lokal, namun makna atau isinya (meaning) digantikan dengan Injil yang berfungsi transformasional (mengubah/membarui) elemen budaya tersebut. ${ }^{37}$

Untuk memperkenalkan Tuhan Yesus Kristus bagi masyarakat Baliem, seorang penginjil dapat menggunakan sebutan Walhowak atau Nakmarugi atau Naruekul, namun tetap menjelaskan keunikan Walhowak Yesus Kristus sebagai Nyopase Kain yang menjadi manusia (Apuni) untuk menebus (oko hike atau ninoko arat palek) dan menyelamatkan (yamagakite) manusia dari dosa (nyaweak) sesuai dengan yang dinyatakan Alkitab. Untuk mengungkapkan karya Walhowak Yesus Kristus dalam

\footnotetext{
${ }^{36}$ Pembahasan yang baik mengenai misi yang utuh (holistic missions) dapat dibaca dalam buku-buku tulisan dari Christopher Wright, The Mission Of God (Downers GroveIllinois: Inter Varsity Press Academic, 2006) dan Misi Umat Allah (Jakarta: Literatur Perkantas, 2016); Lihat juga Arthur F. Glasser, Announcing The Kingdom: The Story Of God's Mission In The Bible (Grand Rapids: Baker Academic, 2008).

${ }^{37}$ Yakob Tomatala, Teologi Kontekstualisasi, 41-42.
} 
menyelamatkan manusia, maka perlu dijelaskan mengenai pengorbananNya di kayu salib untuk menghapuskan dosa (hotarek meke yi hotuke meke) melalui kuasa darah-Nya. Bukan dengan mengorbankan babi (wam) untuk menghapuskan dosa dan kesalahan seperti yang sering terjadi dalam upaya perdamaian setelah perang (wim abiyokoi), tetapi oleh pengorbanan dan kuasa darah Walhowak Yesus Kristus (Roma 5:9). Hal ini menjadi anjuran untuk memperkenalkan Yesus Kristus yang kontekstual bagi masyarakat Baliem karena masyarakat Baliem sampai saat ini tetap mengakui kepercayaan kepada Walhowak sebagai Tuhan menurut agama adat atau budaya sekalipun gereja sudah ada. Menurut mereka, Yesus datang mendamaikan kita dari kehidupan yang buruk. Bagi masyarakat Baliem, Tuhan Yesus Kristus menyempurnakan apa yang mereka percaya. Jadi sampai saat ini orang Baliem tetap pegang budaya yang diberikan Tuhan tersebut.

Namun pada sisi lain, kepercayaan kuno masyarakat Baliem memiliki perbedaan dengan makna hakikat Injil juga. Kepercayaan terhadap areagun nyopa nyapu atau alawene oan kigidekma (roh-roh leluhur) atau roh orang mati (wa laga meke areagun) yang kerapkali dipraktikkan melalui kepercayaan kepada batu keramat kaneke dan mencari petunjukpetunjuk gaib dalam kehidupan sehari-hari melalui kekuatan Kugi Erimbo/Kwewanakwe dan atou perlu mengalami penggantian pandangan dunia (worldview substitute). Kepada masyarakat Baliem harus dijelaskan bahwa yang disebut areagun nyopa nyapu atau alawene oan kigidekma atau juga wa laga meke areagun tidak lain adalah orang-orang pada masa lalu yang merupakan nenek moyang mereka yang sudah lama meninggal. Bahkan sebenarnya kepercayaan kepada roh-roh leluhur yaitu wa laga meke areagun atau alawene oan kigidekma tersebut telah menjadi media dari roh-roh jahat (mokat) yang merupakan musuh Walhowak Yesus Kristus dan manusia yang hanya akan membinasakan manusia (Yohanes 10:10).

Dengan demikian, upaya pemberitaan Injil yang kontekstual bagi masyarakat Baliem dalam kaitannya dengan kepercayaan kuno mereka tidak sekadar menyangkut pertemuan konsep atau kebenaran semata, tetapi melibatkan pertemuan kuasa atau peperangan rohani (spiritual warfare). Penginjilan kontekstual kepada masyarakat Baliem harus berupa penjelasan yang memadai mengenai pribadi dan karya Tuhan (Walhowak) sebagai pencipta (Walhowak pogot kenak helalike meke), penebus (Walhowak ninoko palike meke) dan pemelihara kehidupan (Walhowak kulik lago) sesuai dengan yang dinyatakan dalam Alkitab. Masyarakat Baliem juga harus diyakinkan bahwa wa laga meke areagun atau alawene oan kigidekma, kaneke, atou tidak lain merupakan ekspresi dari kuasa kegelapan (mokat) yaitu 
"ilah zaman" yang membutakan mereka akan cahaya Injil tentang kemuliaan Walhowak Yesus Kristus (2 Korintus 4:4).

KonsepPendekatan Penginjilan Kontekstual Melalui Kepercayaan Akan Masa Depan, Hidup Kekal dan Keselamatan

Secara panjang lebar telah diungkapkan bahwa melalui mitologi Nabelan-Kabelan dan Naruekul mengandung makna bahwa masyarakat Baliem sedang menantikan pengharapan mesias/kargoisme, baik situasi dan kondisi ideal dan damai sejahtera melalui peristiwa "penggantian kulit lama dengan kulit baru" (Nabelan-Kabelan) maupun oknum atau pribadi ideal manusia sekaligus Tuhan yang memberikan hidup dan janji keselamatan turun-temurun kepada masyarakat. Pribadi atau oknum tersebut adalah Naruekul.

Baik situasi yang ideal menurut pengharapan akan Nabelan-Kabelan maupun oknum yang ideal menurut pengharapan akan Naruekul tersebut diyakini oleh masyarakat Baliem bukan berasal dari situasi maupun pribadi di dalam masyarakat, melainkan berasal dari luar masyarakat Baliem yang muncul secara adikodrati. Karena itu, konsep pendekatan penginjilan Kontekstual kepada masyarakat Baliem memiliki jalan masuk dengan memberi makna baru terhadap mitologi Nabelan-Kabelan dan Naruekul dengan hakikat dan makna Injil menurut Alkitab.

Berkaitan dengan konsep hidup kekal yang dihayati oleh masyarakat Baliem dalam mitologi Nabelan-Kabelan, maka dapat menggunakan cerita tersebut. Cerita mengenai Nabelan-Kabelan harus memiliki perubahan atau pembaruan yaitu pemberitaan mengenai "ciptaan baru atau hidup baru yang diberikan kepada setiap orang yang percaya kepada Tuhan Yesus Kristus sebagai Tuhan dan Juruselamatnya" sebagai hakikat dari Injil (2 Korintus 5:17). Dengan demikian implikasi dari karya Kristus yaitu bahwa manusia yang percaya kepada-Nya menjadi "ciptaan yang baru" hendaknya diinkulturasikan dalam status yang harmoni dengan mitologi Nabelan- Kabelan yang mengharapkan adanya "pergantian kulit lama dengan kulit baru". Demikian pula dengan pengajaran Injil mengenai "hidup kekal" yang diberikan sebagai anugerah kepada manusia yang memercayai Tuhan Yesus Kristus sebagai Tuhan dan Juruselamat (Yohanes 3:16; Kisah Para Rasul 16:31) diinkulturasikan dalam keharmonisan pemahaman masyarakat Baliem mengenai "hidup kekal" menurut Nabelan-Kabelan. Dengan demikian, maka Yesus Kristus dapat diperkenalkan dan dipahami oleh orang Baliem sebagai ari apuni yamagati lago atau apuni yamagga suguke atau Juruselamat mereka. Hal ini menjadi anjuran untuk memperkenalkan Yesus Kristus sebagai Juruselamat yang kontekstual bagi masyarakat Baliem. Dengan memperkenalkan Yesus Kristus, maka masyarakat Baliem mengakui 
bahwa kehadiran Yesus ke dalam dunia membawa pendamaian dan juga keselamatan kekal atau Nabelan-Kabelan. Tuhan Yesus sebagai yang dinantikan dalam kepercayaan Nabelan-Kabelan sebab makna dari NabelanKabelan adalah keselamatan kekal. Terima Yesus sendiri adalah terima Nabelan-Kabelan. Masyarakat Baliem sangat memercayai konsep kepercayaan Nabelan-Kabelan ini karena ada hubungan yang erat antara cerita rakyat yang dimiliki oleh masyarakat Baliem tentang konsep hidup yang akan ada setelah sebuah kematian atau hidup kekal dan apa yang digambarkan Yesus dalam Alkitab dalam Yohanes 3:16. Konsep kepercayaan ini masih sangat kuat di masyarakat Hubula karena ada hubungan yang erat antara kepercayaan lokal tentang kehidupan kekal setelah kematian dengan apa yang disampaikan Yesus dalam Alkitab.

Pengajaran Kristen mengenai "kebangkitan orang mati" serta pengharapan "kebangkitan dan hidup baru" dalam Kerajaan Allah/Kerajaan Sorga sebagai situasi ideal, damai sejahtera dan kekal (Filipi 3:20) juga dapat dinkulturasikan secara harmoni dengan nilai budaya masyarakat Baliem yang merindukan situasi masa depan yang harmoni, damai, aman, bahagia dan sejahtera seperti yang dihayati dalam mitos Nabelan-Kabelan tersebut. Sekalipun demikian penekanan utama adalah kepada Pribadi dan Karya Walhowak Yesus Kristus yang adalah "kebangkitan dan hidup" (Yohanes 11:25).

Proses inkulturasi Injil juga memiliki jalan masuk melalui mitos Naruekul dengan menggunakan cerita Naruekul yang dihayati oleh orang Baliem sebagai manusia dan Tuhan (Walhowak) yang telah mati karena dibunuh, namun tetap berkuasa dan memiliki perjanjian kekal. Bukankah yang menjadi inti Injil adalah mengenai pribadi dan karya Tuhan Yesus Kristus adalah manusia dan Tuhan yang telah mati di salib karena dosadosa manusia, namun bangkit kembali pada hari yang ketiga (1 Korintus 15:1-4), serta membuat "perjanjian baru" bagi mereka yang percaya kepada-Nya. Perjanjian Baru tersebut adalah "kehidupan kekal" di rumah Bapa atau Kerajaan Sorga (Yohanes 14:2-3). Demikian pula dengan karya Tuhan Yesus Kristus, yang kematian-Nya di kayu salib adalah korban pengganti/penebusan untuk dosa-dosa manusia (Yohanes 1:29; Efesus 1:7) memiliki kemiripan dengan pribadi Naruekul yang juga mati namun bangkit dan menampakkan diri serta memberikan pesan/janji seperti yang dihayati masyarakat Baliem.

Adanya proses dekulturasi pada saat Injil diperhadapkan dengan nilai budaya masyarakat Baliem, Papua supaya tidak terjadi penyimpangan pengajaran Injil yang memiliki otoritas mutlak maupun sinkretisme yang berlebihan. Seperti yang telah diungkapkan di atas bahwa penghayatan konsep hidup kekal menurut mitologi NabelanKabelan maupun Naruekul memiliki krisis, sebab dalam kedua legenda 
tersebut terdapat nilai-nilai animisme-dinamisme-spiritisme atau penyembahan berhala/kuasa kegelapan yang sangat ditentang oleh Injil/Alkitab.

Oleh karena itu, perlu adanya proses dekulturasi dalam hal-hal tertentu pada mitos Nabelan-Kabelan maupun Naruekul, jika Injil hendak diberitakan dan dihayati dalam konteks budaya masyarakat Baliem. Kembali lagi bahwa kepercayaan terhadap roh-roh leluhur (wa laga meke areagun atau alawene oan kigidekma) yang kerapkali dipraktikkan melalui kaneke serta mencari petunjuk-petunjuk gaib dalam kehidupan sehari-hari perlu mengalami penggantian pandangan dunia (worldview substitute). Kepada masyarakat Baliem perlu diterangkan bahwa yang disebut wa laga meke areagun atau alawene oan kigidekma yang nampak dalam kepercayaan terhadap penguasa alam gaib yang disebut Kugi Erimbo/Kwewanakwe dan limbu serta kepercayaan akan kaneke yang dipercayai sebagai potongan jenazah Naruekul, sebenarnya adalah roh-roh jahat (mokat) yang merupakan musuh Tuhan Yesus Kristus dan manusia yang hanya akan membinasakan manusia (Yohanes 10:10). Dengan demikian, upaya pemberitaan Injil yang kontekstual bagi masyarakat Baliem dalam kaitannya dengan kepercayaan kuno mereka tidak sekadar menyangkut pertemuan konsep atau kebenaran semata, tetapi melibatkan pertemuan kuasa atau peperangan rohani (spiritual warfare). Masyarakat Baliem juga harus diyakinkan bahwa wa laga meke areagun atau alawene oan kigidekma dan benda-benda keramat seperti kaneke tidak lain merupakan kuasa kegelapan (mokat) atau "ilah zaman" yang membutakan mereka akan cahaya Injil tentang kemuliaan Tuhan Yesus Kristus (2 Korintus 4:4).

Penghayatan terhadap kaneke yang kerap menimbulkan budaya "perang suku" dalam kehidupan masyarakat Baliem masa lalu serta potensi yang sama masih sewaktu-waktu dapat muncul pada masa kini. Superioritas Injil yang memberitakan bahwa Tuhan Yesus Kristus membawa "damai sejahtera" harus mendapatkan penekanan (2 Korintus 5:18-20; Efesus 2:13-14).

Proses dekulturasi juga harus terjadi dalam mitos Nabelan-Kabelan berkaitan dengan kepercayaan terhadap legenda burung Ibibilo atau Pirigobit dan ular Bonon. Masyarakat Baliem harus diajarkan bahwa "penggantian kulit lama dengan kulit baru" atau "penggantian kematian dengan kehidupan" tidak bergantung pada kekuatan makhluk hidup dan alam semesta, termasuk binatang seperti burung dan ular. Namun proses perubahan hidup (transformasi) adalah pekerjaan Roh Kudus yang mengubahkan setiap orang yang percaya pada Tuhan Yesus Kristus menurut karakter Kristus (Roma 8:26; Efesus 2:10)

Pada akhirnya Injil sebagai otoritas tertinggi dari segala budaya harus melakukan operasi transformasi budaya atau proses rekulturasi. 
Hal ini memungkinkan terjadi dalam konsep hidup kekal masyarakat Baliem terkait dengan mitos Nabelan-Kabelan maupun Naruekul.

Berkaitan dengan kepe rcayaan kuno masyarakat Baliem terhadap Walhowak, maka seorang pemberita Injil tetap dapat menggunakan istilah (form) Walhowak dalam menyampaikan Injil dengan makna (meaning) yang berbeda dengan pemahaman masyarakat Baliem. Hal ini dimungkinkan dengan adanya fungsi peran pengganti (functional substitute), yaitu upaya mempertahankan istilah atau bentuk (form) seperti yang dikenal dalam konteks lokal, namun makna atau isinya (meaning) digantikan dengan Injil yang berfungsi transformasional (mengubah/membarui) elemen budaya tersebut. Secara khusus untuk memperkenalkan Tuhan Yesus Kristus bagi masyarakat Baliem, seorang penginjil dapat menggunakan sebutan Walhowak atau Nakmarugi atau Naruekul, namun tetap menjelaskan keunikan Walhowak Yesus Kristus sebagai Nakmarugi atau Naruekul, yang menjadi manusia (apuni) untuk menebus (ninoko palike meke) dan menyelamatkan (yamagakite) manusia dari dosa (nyaweak) sesuai dengan yang dinyatakan Alkitab. Untuk mengungkapkan karya Walhowak Yesus Kristus dalam menyelamatkan manusia, maka perlu dijelaskan mengenai pengorbanan-Nya di kayu salib untuk menghapuskan dosa melalui kuasa darah-Nya. Bukan dengan mengupayakan dengan perbuatan sendiri akan kondisi ideal seperti dalam mitos Nabelan-Kabelan atau dengan bantuan benda keramat kaneke seperti dalam mitos Naruekul, tetapi oleh anugerah dan kuasa darah Walhowak Yesus Kristus (Efesus 2:8-9; Roma 5:9).

Pemberitaan inti Injil mengenai Pribadi Tuhan Yesus Kristus juga dapat menggunakan pendekatan dengan kepercayaan masyarakat Baliem terhadap pribadi Naruekul. Pribadi Naruekul yang adalah manusia dan Walhowak yang telah mati terbunuh, namun berkuasa menampakkan dirinya serta bangkit dan naik ke langit sebenarnya adalah Walhowak Yesus Kristus yang memang benar-benar pernah mati tersalib, dibunuh karena menggantikan manusia yang berdosa. Namun pada hari yang ketiga Walhowak Yesus Kristus telah bangkit kembali dan menyatakan diri-Nya kepada para murid serta memberikan "perjanjian baru" yaitu hidup kekal serta naik ke sorga dan akan datang kembali sebagai Raja Kemuliaan. Hal inilah yang menjadi penekanan berita Injil yang harus membarui nilai budaya masyarakat Baliem.

Demikian pula dengan konsep Nabelan-Kabelan diberi makna baru sebagai keselamatan atau hidup kekal, yaitu anugerah dan pemberian istimewa bagi manusia yang percaya kepada Walhowak Yesus Kristus sebagai Walhowak dan ari apuni yamagati lago atau apuni yamaga suguke atau Juruselamat yaitu Kerajaan Allah yang kekal. Status hidup kekal diterima dan dialami pada saat seseorang percaya kepada Kristus, namun 
penggenapan sepenuhnya akan terwujud pada saat Walhowak Yesus Kristus datang kembali sebagai Naruekul sejati. Dengan demikian yang dituntut oleh Walhowak Yesus Kristus kepada masyarakat Baliem secara pribadi dan komunitas adalah memercayai Dia sebagai Walhowak dan ari apuni yamagati lago atau apuni yamaga suguke atau Juruselamat serta berpegang teguh hanya kepada Walhowak Yesus Kristus sebagai Naruekul sejati.

Seperti yang telah diungkapkan bahwa pandangan dunia orang Baliem mengenai keselamatan atau nyewe hanorogo yagelogosak yang bersifat sekarang dan kongkrit (down to earth salvation). Bagi orang Baliem, keselamatan adalah suatu pengalaman hidup baik yaitu terpenuhinya semua aspek kebutuhan dalam hidup yaitu sehat, sukses, subur, hormat serta memiliki pengaruh atas orang lain. keselamatan juga berarti terhindarnya manusia dari hal-hal yang negatif dalam segala aspek kehidupan seperti sakit, kekalahan, kegersangan, kemiskinan dan kematian. Untuk keselamatan yang bersifat sekarang, orang Baliem juga mengandalkan kaneke dengan kekuatannya yang disebut atou yang dapat memberikan perlindungan dan pemeliharaan dalam proses kehidupan sehari-hari, di samping kehadiran roh nenek moyang (wa laga meke areagun atau alawene oan kigidekma) yang dianggap kehadirannya memberikan pertolongan.

Melalui mitologi Nabelan-Kabelan dan Naruekul, orang Baliem juga memiliki pengharapan keselamatan masa depan namun bersifat material. Konsep orang Baliem yang tidak jelas mengenai dosa (apa, bagaimana, kepada siapa, penyebab, akibat dan jalan keluar dari dosa) membuat mereka tidak mengenal adanya keselamatan yang bersifat rohani.

Seorang penginjil kontekstual harus menyatakan dengan jelas kepada orang Baliem mengenai realitas surga (pogot owa) yaitu tempat Walhowak tinggal dalam kekekalan maupun realitas neraka (hetuacmo) sebagai tempat terpisahnya manusia dari Walhowak. Demikian pula dengan realitas penghakiman yang akan membuat eksistensi akhir dari manusia akan menjadi nyata, yaitu yang memercayai Walhowak Yesus Kristus sebagai ari apuni yamagati lago atau apuni yamaga suguke (Juruselamat) akan bersama dengan Dia selama-lamanya di pogot owa serta yang menolak Walhowak Yesus Kristus akan terpisah selama-lamanya dengan Dia dan akan menempati hetuacmo.

Ortodoksi konsep keselamatan menurut Alkitab harus ditekankan dalam pemberitaan Injil kontekstual kepada orang Baliem. Keselamatan berasal dari Walhowak sebagai inisiator sekaligus yang telah mengerjakan keselamatan tersebut (Mazmur 98; Efesus 2:8-9). Keselamatan bukan merupakan hasil usaha dan kemampuan manusia. Manusia tidak akan 
dapat menyelamatkan dirinya sendiri. Manusia pada dasarnya melawan Walhowak sebagai sumber-asal kehidupan ini. Keselamatan adalah karya Walhowak yang dikerjakan dan diterapkan oleh Walhowak sendiri (Efesus 1:3-14). Walhowak sendiri yang menyelamatkan manusia dari murka yang akan datang. Keselamatan tersebut telah dikerjakan oleh Walhowak sendiri, yang mana Dia datang ke dalam dunia, menjelma menjadi manusia. Dialah Walhowak Yesus Kristus yang melakukan karya penebusan melalui kematian-Nya di kayu salib Golgota.

Sekalipun kematian Tuhan Yesus Kristus dalam Injil berbeda hakikatnya dengan mitos Naruekul di atas, namun cerita pengorbanan Yesus Kristus tersebut dapat memanfaatkan bentuk (form) cerita dalam mitos Naruekul. Adapun bentuk dari cerita itu dapat digunakan sebagai sarana untuk mengarahkan orang Baliem Naruekul dalam memahami penerapan konsep keselamatan melalui Pribadi dan karya Yesus Kristus. Adapun "isi" (content) atau "makna" (meaning) dari cerita dalam mitos Naruekul harus mengalami worldview substitute maupun functional substitute sesuai dengan ajaran Injil.

Seorang penginjil kontekstual dapat memberitakan bahwa untuk menyelamatkan manusia dari dosa yang mengakibatkan murka dan penghukuman dari Allah, maka Walhowak atau Naruekul Yesus Kristus telah memberikan nyawa-Nya. Karena itu, maka tubuh dan darah (hepiri okenpalek) Naruekul Yesus Kristus yang menggantikan orang berdosa sehingga memperoleh pengampunan dosa dan keselamatan. Kepada orang Baliem harus diberikan penekanan bahwa manusia tidak dapat melakukan apapun untuk menghilangkan dan menghapuskan dosadosanya sendiri. Hanya melalui Pribadi dan karya Walhowak Yesus Kristus sebagai Naruekul sejati yang bisa menyelesaikan masalah dosa manusia. Oleh karena itu, hanya melalui Dia saja manusia dapat mengenal Walhowak sebagai sumber-asal yang benar (Yohanes l:18).

Konsep keselamatan orang Baliem yang bersifat sekarang dan kongkrit memperoleh pijakan dengan memberitakan Yesus Kristus sebagai Walhowak yang memberikan keselamatan yang utuh. Karena Walhowak Yesus Kristus juga menjanjikan penyertaan dan pemeliharaan setiap hari (Matius 28:20; Ibrani 13:5). Keselamatan yang dikerjakan dan ditawarkan oleh Walhowak Yesus Kristus adalah seutuhnya karena Yesus Kristus adalah Mesias, Raja Damai (Yesaya 9:5). Istilah של שshalom digunakan sebagai keadaan ideal dalam Perjanjian Lama. Sedangkan istilah Yunaninya (dalam Septuaginta /LXX dan Perjanjian Baru) yang digunakan adalah kata "Eịńvๆ/Eirene" yang artinya adalah keadaan yang bebas dari gangguan atau kekacauan serta menunjukkan suasana damai, aman, tertib dan sejahtera. Adapun של של/shalom atau عipńvn/Eirene berarti 
hubungan yang baik antara manusia dengan Allah, dengan pengertian bahwa satu-satunya sumber sejahtera itu adalah Allah, di mana seseorang yang telah diperdamaikan dengan Allah, dia telah memperoleh של /shalom atau eị̄́vๆ/Eirene itu yaitu keamanan, kemakmuran, suasana damai, keadilan dan kesejahteraan, keselamatan dan kesenangan. Demikian juga

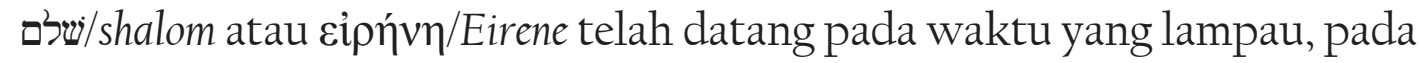
masa kini dan di sini, dan yang akan datang pada akhir zaman. ${ }^{38}$ Dengan demikian pemberitaan mengenai Yesus Kristus sebagai inti dari Injil memenuhi harapan orang Baliem akan "keadaan yang ideal" dalam mitos Nabelan-Kabelan maupun "oknum atau pribadi yang ideal" dalam mitos Naruekul.

Konsep Pendekatan Penginjilan Kontekstual Melalui Sistem Kepemimpinan Tradisional

Berkaitan sistem kepemimpinan atau at hagasek werekma orang Baliem yang menekankan kekuatan, keberanian, kemampuan, kewibawaan dan hikmat seseorang yaitu ap kain maka merupakan bagian penting dalam pendekatan penginjilan kontekstual kepada mereka. Orang Baliem memaknai ap kain atau ap kaintek atau ap koktek sebagai alon werek atau "orang besar berpengaruh dan berwibawa". Pemimpin tersebut dikenal juga sebagai laki-laki pemberani (ap ayukdek) dan laki-laki yang memiliki hati baik (apetaiken werek atau etaikan hano).

Seperti yang telah diungkapkan bahwa sikap loyalitas kepada pemimpin (ap kain) telah menjadi nilai budaya masyarakat Baliem. Pendekatan terhadap para ap kain merupakan pendekatan yang ideal dalam penginjilan kontekstual kepada masyarakat Baliem. Seorang penginjil kontekstual harus melakukan pendekatan kepada para ap kaintek mulai dari ap kain tingkat perumahan (uma), pemukiman (silimo), perkampungan (oukul), sampai kepada tingkat kelompok yang lebih besar dengan memberitakan Injil terlebih dahulu kepada mereka sehingga pada saat mereka memercayai Walhowak Yesus Kristus sebagai ari apuni yamagati lago atau apuni yamaga suguke atau Juruselamat, maka akan mempermudah pemberitaan Injil kepada pengikut mereka sesama orang Baliem lainnya.

Dengan melakukan pendekatan kepada para pemimpin (ap kaintek) akan mempermudah pendekatan kepada masyarakat luas untuk memberitakan Injil yang kontekstual. Apabila pemimpin tersebut telah mendengar dan memercayai Walhowak atau Naruekul Yesus Kristus dan karya keselamatan-Nya, maka akan mempermudah masyarakat untuk

${ }^{38}$ Agus A. Alua, Karakteristik Dasar Agama-agama Melanesia, 49. 
mendengar dan memercayai Walhowak Yesus Kristus sebagai inti dari berita Injil atau Allahene palek.

\section{Kesimpulan}

Dalam artikel ini tampak bahwa masyarakat Baliem sebagaimana orang Papua pada umumnya memiliki pengharapan mesianis cargo cults mengenai adanya masa depan yang ideal melalui mitologi Nabelan-Kabelan atau Nawulal-Hawulal atau Nabudlal-Habudlal atau Nabutal-Habutal atau Nanggonok-Kanggonok. Di sinilah pentingnya peran seorang penginjil yang menghargai dan mengakomodasikan nilai-nilai budaya masyarakat Baliem mengenai pengharapan keselamatan masa depan melalui mitos Nabelan-Kabelan dalam pendekatan Injil yang kontekstual kepada mereka. Cerita mengenai Nabelan-Kabelan harus memiliki perubahan atau pembaruan yaitu pemberitaan mengenai "ciptaan baru atau hidup baru yang diberikan kepada setiap orang yang percaya kepada Tuhan Yesus Kristus sebagai Tuhan dan Juruselamatnya" sebagai hakikat dari Injil (2 Korintus 5:17). Konsep Nabelan-Kabelan diberi makna baru sebagai keselamatan atau hidup kekal, yaitu anugerah dan pemberian istimewa bagi manusia yang percaya kepada Walhowak Yesus Kristus sebagai Walhowak dan ari apuni yamagati lago atau apuni yamaga suguke atau Juruselamat yaitu Kerajaan Allah yang kekal. Penginjilan kontekstual dapat dilaksanakan dengan menyatakan bahwa status hidup kekal sebagaimana yang menjadi pengharapan dalam cerita Nabelan-Kabelan tersebut dapat diterima dan dialami pada saat seseorang percaya kepada Yesus Kristus, namun penggenapan sepenuhnya akan terwujud pada saat Walhowak Yesus Kristus datang kembali

Artikel ini juga menunjukkan bahwa masyarakat memiliki konsep mesianis cargo cults lainnya yaitu pengharapan adanya oknum yang ideal melalui mitos Naruekul atau Nakmarugi. Adapun oknum Naruekul dihayati oleh orang Baliem sebagai manusia dan Tuhan (Walhowak) yang telah mati karena dibunuh, namun tetap berkuasa dan memiliki perjanjian kekal. Cerita Naruekul memiliki kemiripan dengan kisah dan pribadi Yesus Kristus yang mati namun bangkit dan menampakkan diri serta memberikan pesan/janji seperti yang menjadi inti pemberitaan Injil.

Melalui mitologi Nabelan-Kabelan dan Naruekul, orang Baliem memiliki pengharapan keselamatan masa depan yang bersifat material. Konsep orang Baliem yang tidak jelas mengenai dosa (apa, bagaimana, kepada siapa, penyebab, akibat dan jalan keluar dari dosa) membuat mereka tidak mengenal adanya keselamatan yang bersifat rohani. Karena itulah perlu menggantikan pemahaman orang Baliem mengenai keselamatan atau nyewe hanorogo yagelogosak dengan pandangan soteriologi 
Alkitab. Pemahaman orang Baliem mengenai keselamatan tidak hanya mengalami functional substitute (fungsi peran pengganti), melainkan harus menggantikan keseluruhan pandangan dunia mereka secara total (worldview substitute) mengenai konsep keselamatan tersebut. Konsep orang Baliem yang tidak memberikan penekanan kepada "hidup yang akan datang bersama Walhowak Yesus Kristus selama-lamanya," harus digantikan dengan konsep keselamatan seperti yang dinyatakan dalam Alkitab.

Artikel ini juga menunjukkan betapa kuatnya penghormatan dan ketaatan orang Baliem kepada sistem kepemimpinan tradisional ap kain. Para ap kain dikenal sebagai pemimpin karismatik yang memiliki kemampuan dan kuasa serta pengaruh yang besar untuk menggerakkan segala sikap, tindakan, keputusan, kegiatan dan tingkah laku masyarakat Baliem. Sikap loyalitas terhadap pemimpin ini menentukan masyarakat untuk berperilaku (behavior) dalam memilih agama yang dianut, terbuka terhadap pengaruh dunia luar (akulturasi) dan perkembangan masyarakat lainnya. Karena itu, penulis menganjurkan penginjilan kontekstual dengan "model akomodasi" sebagai model yang relevan untuk diterapkan berkaitan dengan sikap loyalitas masyarakat kepada ap kain sebagai pemimpin orang Baliem

Nilai-nilai yang terkandung dalam kesetiaan orang Baliem terhadap ap kain diterapkan juga dalam mengambil keputusan untuk memilih agama yang dianut secara komunal. Sikap hormat kepada ap kain sebagai pemimpin atau "kepala suku" dapat diakomodasi dan diletakkan pada tempat yang sebenarnya, yaitu sikap dan tindakan percaya dan setia kepada Walhowak Yesus Kristus. Pada akhirnya sikap hormat kepada ap kain dapat diberi arti yang baru yaitu, saling mengasihi dan melayani dengan setia terhadap sesama orang percaya serta sesama manusia lainnya sebagai wujud hormat dan setia kepada Wahowak Yesus Kristus.

\section{Kepustakaan}

Alua, Agus. Karakteristik Dasar Agama-agama Melanesia. Abepura-Jayapura: Biro Penelitian STFT Fajar Timur, 2006.

Nilai-nilai Hidup Masyarakat Hubula di Lembah Balim Papua. AbepuraJayapura: Biro Penelitian STFT Fajar Timur, 2006.

Permulaan Pekabaran Injil di Lembah Balim. Abepura-Jayapura: Biro Penelitian STFT Fajar Timur, 2006.

Wenewolok di Le mbah Balim, Jayawijaya, Papua: Arti dan Makna Sosiologis, Biblis dan Teologis. Abepura-Jayapura: Biro Penelitian STFT Fajar Timur, 2007. 
Asso, Masmur (ed.). Kamus Bahasa Indonesia-Hubula: Bahasa Daerah Suku Hubula Kabupaten Jayawiaya. Wamena: Dinas Kebudayaan dan Pariwisata Kabupaten Jayawijaya, 2016.

Boelaars, Jan. Manus ia Irian-Dahulu, Sekarang, Masa Depan. Jakarta: Gramedia Pustaka Utama, 1986.

Giay, Benny. Kargoisme di Irian Jaya. Sentani: Region Press, 1986.

Glasser, Arthur F. Announcing the Kingdom: The Story of God's Mission in the Bible. Grand Rapids: Baker Academic, 2008.

Gilliland, Dean. The Word Among Us-Contextualizing Theology for Mission Today. Dallas: Word Publishing, 1989.

Hiebert, Paul G. Anthropological Insights for Missionaries. Grand Rapids: Baker Academic, 1985.

. Cultural Anthropology. Michigan: Baker Book House, 1998.

Koentjaraningrat. Masyarakat Terasing di Indonesia. Jakarta: Gramedia Pustaka Utama, 1993.

.Irian Jaya: Membangun Masyarakat Majemuk. Jakarta: Penerbit Djambatan, 1994.

Kraft, Charles. Christianity in Culture: A Study in Dynamic Biblical Theologizing in Cross Cultural Perpective. Maryknoll-New York: Orbis, 1979. 1996.

. Anthropology for Christian Witness. Maryknoll-New York: Orbis,

Lieshout, Frans. Sejarah Gereja Katolik di Lembah Balim-Papua. AbepuraJayapura: Sekretariat Keuskupan Jayapura, 2009.

Mansoben, Johszua Robert. Sistem Politik Tradisional di Irian Jaya, Indonesia. Amsterdam: Universitas Leiden, 1994.

Medlama, Marthen Yadlogon. Welcome to the Baliem Valley Regency Papua. Wamena: Agamua Science, 2009.

Spencer, Aida Besancon. The Global God-Listening to God and Learning From Culture. Grand Rapids: Baker Books, 1998.

Susanto-Sunario, Astrid. Kebudayaan Jayawijaya Dalam Pembangunan Bangsa. Jakarta: Lembaga Ilmu Pengetahuan Indonesia (LIPI) dan Pustaka Sinar Harapan, 1994.

Tomatala, Yakob. Teologi Kontekstualisasi. Malang: Gandum Mas, 2007.

Wenda, Kiloner. Sejarah Gereja Baptis Papua Barat. Jayapura: Persekutuan Gereja-Gereja Baptis Papua, 2009.

Wright, Christopher. The Mission of God. Downers Grove-Illinois: Inter Varsity Press Academic, 2006.

. Keselamatan Milik Allah Kami. Jakarta: Literatur Perkantas Jawa Timur, 2011. . Misi Umat Allah. Jakarta: Literatur Perkantas, 2016. 
Yelipele, Umar. Perkawinan Adat Suku Dani Muslim di Papua. Pamekasan: STAIN Pamekasan, 2012.

Zahniser, Mathias. Symbol and Ceremony-Making Disciples Across Cultures. California: MARC-World Vision International, 1997.

Zollner, Siegfried. Pohon Yeli dan Mitos Wam Dalam Agama Orang Yali. Germany: Penerbit Wahine, 2011. 